\title{
Queers are Workers, Workers are Queer, Workers' Rights are Hot! The Emerging Field of Queer Labor History
}

\author{
Sara R. Smith \\ Berkeley City College and Sonoma State University
}

Allan Bérubé, My Desire for History: Essays in Gay, Community, and Labor History. Chapel Hill: University of North Carolina Press, 2011. 344 pp. \$30.00.

Frank Miriam, Out in the Union: A Labor History of Queer America. Philadelphia: Temple University Press, 2014. 240 pp. \$29.95.

Reay Barry, New York Hustlers: Masculinity and Sex in Modern America. Manchester and New York: Manchester University Press, 2010. 208 pp. \$35.00.

Tiemeyer Phil, Plane Queer: Labor, Sexuality, and AIDS in the History of Male Flight Attendants. Berkeley: University of California Press, 2013. 302 pp. \$29.95.

Gay male stewards performing drag shows on large passenger ships in the 1930s. Male hustlers selling sex to men for money and then going home to their girlfriends in the 1950s. Lesbian bus drivers organizing in the 1970s to include "sexual orientation" in their union contract's antidiscrimination clause. Gay male flight attendants fired from their jobs for being HIV-positive in the 1980s. These are some of the stories told in the four books under review, each about the queer labor history ${ }^{1}$ of the United States.

Influenced by the social movements of the 1960s and 1970s, in the past fifty years historians of labor in the United States have considered how work has been racialized and gendered; they have shed light on how labor unions have both perpetuated gender and racial inequalities at work and how women, people of color, and their allies have utilized their labor unions as vehicles to challenge discrimination in the workplace and in society more generally. At the same time, US queer historians have written about working-class queer life, most notably Elizabeth Kennedy and Madeline Davis's Boots of Leather, Slippers of Gold about working-class lesbians in Buffalo, New York, and George Chauncey's Gay New York, which analyzes the link between class 
and gay identity formation. ${ }^{2}$ The fertile intersection between queer and labor history, however, has been largely overlooked by labor historians and historians of queer history alike. It appears that this is starting to change.

The four recently published books under review are, arguably, a reflection of the emergence of United States queer labor history as a field. Allan Bérubé's My Desire for History, edited by Estelle Freedman and John D'Emilo, presents a variety of Bérubé's writings, including his pioneering work in the field of queer labor history on the Marine Cooks and Stewards Union, a "multiracial, multiethnic, politically radical, and queer-inflected union."3 Phil Tiemeyer's Plane Queer brings labor and queer history together by analyzing the history of gay male flight attendants from the 1930s to the present. Barry Reay's New York Hustlers explores the world of male hustlers, masculine-identified men who had sex with men for money, the majority of whom identified as heterosexual. Miriam Frank's Out in the Union is a broad historical survey of queer labor history from the 1960s to the present. ${ }^{4}$

The labor of male stewards, flight attendants, and hustlers discussed in $M y$ Desire for History, Plane Queer, and New York Hustlers as well as the work of lesbian bus drivers and construction workers in Out in the Union can be referred to as "queer work." Bérubé uses "queer work" in "Queer Work and Labor History," originally published in 1996 and reprinted in My Desire For History, to describe labor performed by LGBT-identified workers, as well as work that involves crossing gender boundaries. For instance, in Plane Queer male flight attendants work in a feminized profession, and of the men who have served as flight attendants many have been gay. Queer work may also consist of jobs in same-sex environments, like jails and the military. ${ }^{5}$ In order to understand how work becomes queer, argues Bérubé, "we'd have to look at how each particular queer job also became racialized and gendered." ${ }^{, 6}$ White gay stewards on luxury liners in the 1930s, for example, were doing personal service work, labor normally reserved for women and people of color.

John D'Emilio and Estelle B. Freedman, pioneers in the field of gay and lesbian history, start My Desire for History with a biographical discussion of Bérubé's beginnings as a community-based historian in the 1970s. Their introduction mixes D'Emilio and Freedman's personal knowledge of Bérubé's life, activism, and scholarship with interviews with friends and family members, as well as archival research. D'Emilio and Freedman emphasize that Bérubé, selftaught and writing outside the academy, was a scholar-activist who sought to uncover gay and lesbian history to help gays and lesbians gain knowledge of themselves. For Bérubé, being a community historian meant bringing gay and lesbian history to a broad audience, which he did by traveling around the country presenting slideshows based on his research. Eschewing academic jargon, Bérubé mines his personal experiences to demonstrate larger concepts, making his writing accessible to a general audience.

Bérubé is most well known for Coming Out Under Fire: The History of Gay Men and Women in World War II. At the time it was published in 1990, there were only about a dozen published books on gay and lesbian history. $M y$ 
Desire for History contains some of Bérubé's writings about the transformative impact of World War Two on lesbians and gay men. During the Second World War, the Selective Service System became a "stigmatizing machine," ultimately rejecting tens of thousands. Bérubé links the oppression experienced by lesbians and gay men during World War Two with the emergence of gays and lesbians as a self-conscious minority, helping to lead to the formation of early gay and lesbian rights organizations, such as the Mattachine Society and the Daughters of Bilitis.

Bérubé was interested in the ways that histories of marginalized communities could help foster social change. A common theme in his writing is that oppression has fostered resistance. As the AIDS epidemic worsened in the 1980s, city officials in San Francisco targeted gay bathhouses for closure as supposed public health hazards. Placing these efforts within a historical context of repeated efforts to close down gay bars and gay bathhouses, Bérubé argues the bathhouses served as venues for the creation of gay and lesbian communities. In the 1950s when San Francisco engaged in a ten-year attempt to close gay and lesbian bars the result was "to transform the gay community into a politically aware minority in local politics." ${ }^{, 7}$ Bérubé argues that closing the bathhouses would only relocate sexual activity. Instead of targeting bathhouses for closure, the city should have viewed them as gay community spaces that could be utilized to promote safe sex practices. In response to the AIDS crisis of the 1980s, San Francisco did ultimately shut down many gay bathhouses, rejecting the arguments made by Bérubé and other supporters of gay bathhouses.

Bérubé's self-reflective and theoretical writings illustrate his decision to incorporate race and class, as well as gender and sexuality, into his scholarship and activism. Bérubé's "How Gay Stays White and What Kind of White It Stays" is a penetrating analysis; he examines a number of "whitenening practices" that have established the normative gay subject as white, male, and affluent. These include the exclusion of gay people of color from white gay spaces; the selling of gay whiteness in ads and mainstream gay activism; racial analogies between the civil rights and gay rights movement; and mirroring, a "political strategy that reflects back the whiteness of the men who run powerful institutions to persuade them to take 'us' seriously, accept 'us,' and let 'us' in because 'we are just like you." "8 Bérubé draws on lessons learned from political activism in spaces comprised mainly of white gay men: his involvement in AIDS activism and his activism against the government's ban on gays and lesbians in the military. The effect of these whitening practices has been the movement's transition from focusing on gay liberation to prioritizing gay pride and lobbying for individual equality within existing institutions. The effect is a racially exclusionary gay politics.

This commitment to an intersectional politics led Bérubé to research the Marine Cooks and Stewards Union (MCSU), a radical, antiracist union with a queer reputation, a project left unfinished at the time of his death in 2007. The last three chapters of My Desire for History contain the writings he 
produced on the subject. The final chapter about the MCSU draws from a slide show presentation Bérubé showed dozens of times around the country, showcasing how the stewards aboard the Matson passenger liners in the 1930s and 1940s - all were white and mostly gay - did queer work, filling jobs normally assigned to women and people of color. They worked as pastry chefs, waiters, bedroom stewards, pursers, wine stewards, florists, hairdressers, and telephone operators. The stewards worked sixteen-hour days and many were "forced to live and work below the waterline with no portholes or fresh air." Yet the gay stewards also created a queer work culture aboard the ships, sometimes organizing drag shows. Bérubé quotes Jim Vieira, a steward who remembered, "In the galley ... or in the dining room, when there weren't any passengers around, all the stewards called each other by girls' names-Miss this and Miss that." The MCSU was destroyed during the antigay and anticommunist hysteria of the $1950 \mathrm{~s}$, as were many other radical unions committed to racial equality. Allan Bérubé's analysis of the use of homophobia, in combination with anticommunism and racism, to destroy the MCSU is unusual; it adds a layer to this history not discussed by labor or queer historians. Many labor historians have written about the effects of anticommunism on the labor movement, ${ }^{9}$ and David K. Johnson and others have shown how homophobia facilitated the dismissal of gay and lesbian workers in the "Lavender Scare." ${ }^{10}$ But Bérubé notes that right-wing union dissidents contributed to the destruction of the Marine Cooks and Stewards Union, not only through redbaiting but also through homophobic attacks on the union.

Overall, Bérubé's approach in My Desire For History involves a definition of queer work that hews closely to the established methods of labor historians. When Bérubé discusses the stewards' conditions of exploitation at work, he is informed by other historians' insights about how labor has historically been racialized and gendered. He examines gay stewards' creation of a queer work culture despite their exploitation, and, importantly, Bérubé focuses on unions - in this case, the Marine Cooks and Stewards-as a key element of labor history.

While Bérubé's concept of queer work informs Phil Tiemeyer's history of gay male flight attendants, the second book under review, Tiemeyer's approach to queer labor history is a significant departure from Bérubé. Tiemeyer concentrates on the legal, economic, and cultural developments that led to the homophobia that influenced the gender makeup of the flight attendant workforce. Although other scholars have traced the history of female flight attendants, Tiemeyer is the first to publish a study on gay, and largely white, male flight attendants. ${ }^{11}$ Tiemeyer contends that male flight attendants' role as "gender misfits and suspected homosexuals ... makes them an important case study of gender discrimination and homophobia in the American workplace." $12 \mathrm{He}$ shows, perhaps surprisingly, that the trajectory of acceptance of gay men as flight attendants was uneven, with the 1930s, 1970s, and 1990s standing out as less homophobic, while the 1950 s and 1980 s were "decidedly antagonistic for gay men working as flight attendants."13 
In the 1930s male stewards constituted one-third of the flight attendant workforce. Men were initially hired as stewards on airlines such as Eastern and Pan Am because work aboard airplanes involved a mixture of masculine and feminine tasks - air travel was quite dangerous until the mid-1930s - and, notes Tiemeyer, "airline executives were uncertain whether the hostile environment required a flight attendant with manly fortitude or the comforting touch of a woman." 14 Though unable to find statistics on the sexual orientation of male stewards in the 1930s, Tiemeyer concludes nonetheless that they were performing queer work. Tiemeyer draws out the intersection of sexuality with gender and race, noting that their status as "white men doing servile 'women's work' or 'colored work' compromised them as failed men and suspected homosexuals." ${ }^{15}$ The disparagement of this work stems from technological advances with the release of more advanced aircraft in 1936 that facilitated the domestication of the aircraft's cabin.

The pre-World War Two acceptance of male stewards gave way after the war to the homophobia of the 1950s. The airlines sought to exclude men from flight attendant work because they could pay female flight attendants less than male stewards, and female flight attendants were supposedly better able to "coddle flying businessmen."16 As men were excluded in the 1950s, women came to predominate. In his discussion of the 1950s, Tiemeyer focuses on the murder of Eastern Airlines steward William Simpson to explain greater negative attention paid to the prevalence of gay male stewards. The two men who killed Simpson did so as part of a scheme to seduce and rob gay men in Miami, Florida. The media attention paid to Simpson's gayness, argues Tiemeyer, motivated airlines to ramp up the exclusion of men from the flight attendant corps. Tiemeyer also offers a detailed account of Diaz v. Pan Am, a legal case that ultimately overturned airline policies against hiring men in the 1970s. At the time more than ninety-six percent of all flight attendants were women, and no airline was hiring male flight attendants. ${ }^{17}$ The case was ultimately successful. Diaz v. Pan Am ushered in a new era in 1971 when airlines started hiring men again, many of them gay. ${ }^{18}$

Tiemeyer's extensive focus on legal history means that he overlooks significant grassroots developments in the 1960s and 1970s. Historian Kathleen Barry shows that at the same time as the Diaz v. Pan Am decision there was a simultaneous upsurge in feminist organizing by female flight attendants as women actively challenged airlines' eroticization of their labor and contested male domination of their unions. ${ }^{19}$ Tiemeyer neglects the relationship between male and female flight attendants, both the moments they came in conflict and the moments in which they organized in solidarity, missing an opportunity to evaluate the influence of rank-and-file organizing by feminist flight attendants and gay stewards on the gender and sexual composition of the flight attendant workforce.

Tiemeyer's analysis of the impact of the AIDS epidemic on flight attendants in the 1980s is particularly sharp. ${ }^{20}$ He discusses the firing of Gär Traynor in 1983 because of his AIDS diagnosis, despite being healthy enough 
to work. The case was brought to labor arbitration in a successful and precedentsetting case, with Traynor winning the right to return to work in $1984 .^{21}$ Tiemeyer also criticizes gay journalist Randy Shilts for perpetuating the patient zero myth, the idea that a single person was responsible for bringing and spreading AIDS to the Western world. Shilts helped to make Gaëtan Dugas "the most infamous steward in history" when he revived the myth in the late 1980s that Dugas helped to spread AIDS because of his sexual promiscuity in various parts of the world (supposedly 250 sexual partners per year). ${ }^{22}$ The impact of the AIDS epidemic on workers' rights is a topic few have covered, making Tiemeyer's discussion a major contribution to queer labor history. His discussion of AIDS, moreover, falls at the intersection of queer and disability studies, both of which merit more attention by labor historians.

Finally, Tiemeyer examines the effects of neoliberal economic policies on the deregulation of the airline industry and the gutting of union power. The airlines' bestowal of increased rights and benefits (nondiscrimination clauses and partner health benefits) from the 1990s onward was due to corporate policies to attract wealthy gay and lesbian travelers, resulting in the corporatization of LGBT rights. ${ }^{23}$ At the same time that the airline industry was marketing itself as LGBT-friendly, it was also weakening flight attendant unions. ${ }^{24}$ Therefore, the corporate bestowal of certain benefits to LGBT flight attendants has to be viewed in the context of simultaneous efforts by airline executives to undervalue and degrade the work of flight attendants as a whole.

Tiemeyer's discussion of legal history, the effects of the AIDS epidemic on the rights of gay male flight attendants, and his analysis of the corporatization of LGBT rights are incisive contributions to queer and labor history. Tiemeyer's examination would have been strengthened by a discussion of organizing within flight attendant unions; this would illustrate that change occurred as a result of rank-and-file organizing at work, not only due to the courtroom and the media.

Barry Reay's New York Hustlers: Masculinity and Sex in Modern America, considers a kind of queer work: men who had sex with other men for money in New York City from the 1940s to the 1960s. Reay, a scholar of English history and the history of sexuality, ${ }^{25}$ focuses specifically on hustlers, who, in contrast to their effeminate counterparts known as "queens," attracted clients based on their performance of masculinity and related assumption that the hustler was normally attracted to women. ${ }^{26}$ A majority of hustlers between the $1940 \mathrm{~s}$ and 1960s identified as heterosexual despite having sex with other men. Reay is in dialog with historians who contend that it was in the post-World War Two period that the modern homosexual identity solidified. ${ }^{27}$ Reay troubles this idea by arguing that the making of a homosexual identity was "more protracted and complex" than many historians have recognized, and that hustlers "sexually traversed homosexuality and heterosexuality, continually negotiating the boundaries of pleasure and self through acts that refuse easy attributions of identity."28

Of the four books under review, Reay's New York Hustlers departs the most from traditional labor history because of its focus on the cultural 
representation of labor. While the other authors utilize archival documents and oral histories as source material, Reay relies on the collection of Thomas Painter, who solicited hustlers starting in the 1930s, providing information to sexologist Alfred Kinsey until the early 1970s. Painter's collection contains a thousand photographs-some of which illustrate New York Hustlers-and fiction, drawings, journals, and home movies. Reay also utilizes archival materials from the Kinsey Institute and analyzes fiction, art, and films. For instance, Reay examines hustler John Rechy's literary work published in the 1960s and 1970 s to examine the transition from a more complex system of sexual diversity prior to the 1970 s to an increasingly binary system in which a person is positioned as either gay or straight. In Rechy's City of Night, published in 1963, the hustlers did not identify as gay because they had sex with men, while Sexual Outlaw, published in 1977, "is a choreographed celebration of homosexuality on the eve of AIDS, a homage to gay masculinity that could only have come from the 1970s." 29 Reay offers many examples of hustlers and trade (hustlers who took on the dominant role in sex) in popular culture to argue that Americans more widely understood that not all men who had sex with other men identified as gay, challenging the view that the homosexual identity had solidified in the immediate years after World War Two.

Reay asserts that homosexuality from the 1940 s to the 1960 s continued to be marked by effeminacy, as it largely had been earlier in the century, rather than only sexual object choice. Masculine-identified men who had sex with other men disparaged effeminate gay men, distancing themselves from the identity of homosexuality by claiming their own masculinity. Gore Vidal, for instance, in his 1948 novel The City and the Pillar, according to Reay, writes of "the 'severe and masculine' Jim" who "is not at all like the 'mincing', 'abnormal', 'effeminate' others." 30

Reay has accomplished a thoroughly researched study, convincingly arguing that the cultural representations of hustlers in New York City from the 1940 s to the 1950 s complicate a clean narrative of the solidification of homosexual identity formation in the years after World War Two years. Though Reay examines a class of workers who often chose their profession at least in part out of economic necessity, he pays little attention to the working conditions of hustlers. Class only enters Reay's study in order to explain the hustler's sexual appeal. ${ }^{31}$ Although Reay faults labor historians for not taking an interest in hustlers, Reay's own study does not consider the material conditions of hustling. ${ }^{32}$

Reay could have strengthened his analysis by infusing a deeper class analysis into his discussion. If Reay were to consider hustlers' economic motivations, his argument would be more convincing. At one point Reay refers to the "sordid reality" of sex work but does not elaborate, leaving the reader without an understanding of the lives led by hustlers. ${ }^{33}$ This absence allows one to imagine that heterosexual-identified hustlers who had sex with men for money did so simply out of economic need, going against Reay's argument that hustlers' sexual practices proved one way or another that homosexuality as an identity was yet to be solidified in the years immediately following World War Two. 
Of the four books under discussion, Miriam Frank's Out in the Union: A Labor History of Queer America is the broadest in its scope, covering the 1960s to the present. Out in the Union is the first historical survey of US queer labor history and is thus a major contribution to queer labor history as a field of study. Like Bérubé, Frank is focused mostly (though not entirely) on the queer history of unions. Though not comprehensive in its geographical coverage, the study nonetheless examines a relatively wide range of sites, including Boston, San Francisco, New York, Los Angeles, Seattle, and Washington, DC. While the other studies focus on particular professions, Frank considers the experiences of various kinds of workers, including bus drivers, workers at AIDS clinics, staff organizers within unions, social workers, teachers, and retail workers. While the other three authors focus on the labor of male-identified workers, Out in the Union includes lesbians, bisexuals, and transgender workers.

In the section "Coming Out," Frank examines people's experiences being queer at work and in unions, giving voice to individual motivations for either coming out or choosing to remain closeted. In "Coalition Politics," Frank examines queer-labor alliances of "national consequence," such as the 1970s boycott of Coors Beer in California owing to the company's antiunion and homophobic policies. ${ }^{34}$ This section also considers the incorporation of queer issues into collective bargaining. In the third section, "Conflict and Transformation," Frank discusses unionization drives at queer-owned businesses and queer service agencies.

Out in the Union uncovers a largely unknown history, in the process offering the beginnings of a chronology of US queer labor history. Frank demonstrates that the 1970s marked a major shift in queer labor history-on the heels of gay liberation. While homophobia and transphobia still prevented many from coming out of the closet at work, queer activists also formed alliances with the labor movement as many began to see their unions as potential vehicles to combat discrimination. The late 1970 s witnessed the rise of the antigay Christian Right, sparking the formation of LGBT coalitions including labor unions, most notably in California against the Briggs Initiative, which, if passed, would have made it illegal to hire gays and lesbians as public school teachers. ${ }^{35}$ In the 1980s, workers in the queer community faced a new stigma-as AIDS became identified with gay men, workers with HIV/AIDS experienced discrimination in the workplace. Service Employees International Union Local 250 issued a pamphlet, "AIDS and the Health Care Worker," which found its way to union locals across the country. ${ }^{36}$ In the 1990 s and 2000s, due to grassroots pressure and increasing acceptance of gays and lesbians, unions became more responsive to the needs of queer workers, culminating in the formal affiliation of Pride at Work, a caucus committed to advancing the rights of queer workers, with the AFL-CIO, the major labor federation in the United States. ${ }^{37}$

Frank excels at centering individual voices in her rendering of queer labor history. Owing to the absence of queerness in union-related archival documents and newspapers, Frank relied on more than one hundred "conversations," as she 
calls them, with queer workers and labor movement activists. Because the study is packed with quotes and individual stories, not only does queer history appear more vibrant, but it is also more nuanced than it might have been otherwise. ${ }^{38}$ Oral histories show how an individual's decision to come out of the closet at work is dependent on various factors, including where in the country one lives, the existence of personal networks of support, workplace cultures, and the progressiveness of their unions. Oral histories, moreover, make the experience of discrimination more palpable.

While the other three authors discussed here focus on men's experiences, Frank is to be commended for including the experiences of lesbian and transgender workers. She, for instance, discusses the "dyke-baiting" endured by lesbians (and straight women) in the construction trades. Frank also examines the organizing of lesbian bus drivers in Ann Arbor, Michigan, in the 1970s and 1980s, who radicalized their AFSCME local and made it one of the first to successfully negotiate over the inclusion of "sexual preference" in their union contract. 39 Though transgender people face a tremendous amount of discrimination at work, little has been written about transgender workers. Though Frank's focus is mostly on gays and lesbians, she does address transgender workers' involvement in the labor movement, in particular concerning health coverage inclusive of transgender-related services and procedures in union contracts. ${ }^{40}$

While Frank emphasizes rank-and-file queer labor activism, she also examines some of the earliest unions to support gay rights at the national level. The American Federation of Teachers, for instance, passed a resolution opposing discrimination against gay teachers at its national convention in 1970, one of the earliest unions to do so. Frank contends that the unions most active in the civil rights and feminist movements also tended to support gay rights earlier than other unions, as did unions that represented a relatively high proportion of queer workers. ${ }^{41}$

Though Out in the Union is an excellent and thoroughly researched study that deserves a wide readership, Frank's emphasis on positive developments around queer rights within the labor movement obscures the troubling orientation of the labor movement toward queer rights. How did the less progressive unions respond to the demands of queer workers within, for instance? How did nominally progressive union leaders perpetuate discrimination against their LGBT members? Additional research about the resistance queer workers faced within their unions when they fought against homophobia and transphobia would shed further light on queer labor history. Out in the Union is a major contribution to both US queer and labor history, revealing largely unknown historical events and themes. By doing so, Frank presents topics ripe for further research, from union campaigns at queer-owned workplaces and alliances between queer activists and the labor movement to workplacebased activism to challenge transphobia.

It is notable that three of the four books reviewed here focus on the experiences of gay white men performing queer work. Overall, the treatment of race across the texts is uneven. Bérubé includes an analysis of race and, to some 
extent, discusses the experiences of African American stewards working on the Alexander passenger liners. Bérubé's analysis also accounts for the ways in which steward work was defined as queer and was racialized as white. On the other hand, Tiemeyer's discussion in Plane Queer could consider the ways that race shaped flight attendant work in more detail. While Puerto Ricans make fleeting appearances in Reay's book, African Americans and other people of color are not present. Out in the Union is broader in its approach, as it cites the experiences of white LGBT people-not just men-as well as queer people of color. Had Miriam Frank, however, made race and ethnicity more central to her analysis, the distinct experiences of queer workers of color and white queer workers would have been drawn out more. As it stands, this review of recently published texts in the field reveals that there is still a need for a labor history focused on queer people of color.

Further, of the four authors only Miriam Frank focuses her discussion on the experiences of lesbian and transgender workers. Only Frank makes the experiences of lesbian workers and union activists as central as she does those of gay men. As noted earlier, she also pays some attention to transgender workers, though there is certainly much work to be done on this topic. ${ }^{42}$

Overall, these four books arguably point to the emergence of queer labor history as a significant new field of study, although it is a field still under construction. They underscore, moreover, that if what we seek is an inclusive history, the class experiences of queer people at work and in their unions merit further attention. These books also reveal what has yet to be writtentexts that allow for closer attention to the intersection of gender, sexuality, race, and ethnicity in queer labor history, as well as the particular histories of bisexual workers.

\section{NOTES}

1. I use "queer" rather than "gay and lesbian" because queer has a broader connotation, referring to lesbian, gay, bisexual, transgender, and other queer-identified people. "Queer" also describes people who express their gender and sexuality in nonnormative ways, but who do not necessarily identify as lesbian, gay, bisexual, or transgender.

2. George Chauncey, Gay New York: Gender, Urban Culture, and the Makings of the Gay Male World, 1890-1940 (New York, 1994); Elizabeth Lapovsky Kennedy and Madeline D. Davis, Boots of Leather, Slippers of Gold: The History of a Lesbian Community (New York, 1994).

3. Allan Bérubé, My Desire for History: Essays in Gay, Community, and Labor History (Chapel Hill, 2011), 28.

4. Also see Miriam Frank, "Hard Hats \& Homophobia: Lesbians in the Building Trades," New Labor Forum 8 (2001): 25-36; Miriam Frank, "Lesbian, Gay and Bisexual Caucuses in the United States Labor Movement," in Laboring for Rights: A Global Perspective on Union Response to Sexual Diversity, ed. Gerald Hunt (Philadelphia, 1999); Miriam Frank, "Lesbians and the Labor Movement," in Encyclopedia of Homosexuality, 2nd ed., volume I: Lesbian Histories and Cultures, ed. Bonnie Zimmerman (New York, 2000).

5. Bérubé, My Desire for History, 263.

6. Ibid., 264.

7. Ibid., 77.

8. Ibid., 209. 
9. See, for example, Robert W. Cherny, William Issel, and Kieran Walsh Taylor, eds., American Labor and the Cold War: Grassroots Politics and Postwar Political Culture (New Brunswick, 2004); Shelton Stromquist, ed., Labor's Cold War: Local Politics in a Global Context (Urbana, IL, 2008); George Lipsitz, Rainbow at Midnight: Labor and Culture in the 1940s (Urbana, IL, 1994).

10. David K. Johnson, The Lavender Scare: The Cold War Persecution of Gays and Lesbians in the Federal Government (Chicago, 2004). Also see Karen Graves, And They Were Wonderful Teachers: Florida's Purge of Gay and Lesbian Teachers (Urbana, IL, 2009); Stacy Lorraine Braukman, Communists and Perverts under the Palms: The Johns Committee in Florida, 1956-1965 (Gainesville, FL, 2012).

11. Kathleen M. Barry, Femininity in Flight: A History of Flight Attendants (Durham, NC, 2007); Georgia Panter Nielsen, From Sky Girl to Flight Attendant: Women and the Making of a Union (Ithaca, NY, 1982).

12. Phil Tiemeyer, Plane Queer: Labor, Sexuality, and AIDS in the History of Male Flight Attendants (Berkeley, CA, 2013), 2.

13. Ibid., 220.

14. Ibid.

15. Ibid., 220-21.

16. Ibid., 222.

17. Barry, Femininity in Flight, 166.

18. Tiemeyer, Plane Queer, 108.

19. Barry, Femininity in Flight, 175.

20. Tiemeyer, Plane Queer, 3.

21. Ibid., 138.

22. Ibid., 137.

23. Ibid., 195. Also see Alexandra Chasin, Selling Out: The Gay and Lesbian Movement Goes to Market (New York, 2000).

24. Tiemeyer, Plane Queer, 196.

25. Kim M. Phillips and Barry Reay, eds., Sex Before Sexuality: A Premodern History (Cambridge, 2011); Sexualities in History: A Reader (New York, 2002); Barry Reay, Watching Hannah: Sexuality, Horror and Bodily De-Formation in Victorian England (London, 2002); Barry Reay, Popular Cultures in England, 1550-1750 (London and New York, 1998).

26. Barry Reay, New York Hustlers: Masculinity and Sex in Modern America (Manchester, NY, 2010), 5.

27. For example, Chauncey, Gay New York: Gender, Urban Culture, and the Makings of the Gay Male World, 1890-1940.

28. Reay, New York Hustlers, 17.

29. Ibid., 242.

30. Ibid., 174.

31. Ibid., 101.

32. Ibid., 105.

33. Ibid., 224.

34. Miriam Frank, Out in the Union: A Labor History of Queer America (Philadelphia, 2014), 9, 76-77, 88-89.

35. Ibid., 88, 121.

36. Ibid., 119.

37. Ibid., 97.

38. Ibid., 11.

39. Ibid., 21, 105-7.

40. Ibid., 3 .

41. Ibid., 18, 83-84.

42. Ann Balay's Steel Closets: Voices of Gay, Lesbian, and Transgender Workers (Chapel Hill, NC, 2014), like Frank, begins to rectify the absence of transgender workers from queer labor history. 